\title{
TLQP-21 modulate inflammation and fibrosis in a model of ards
}

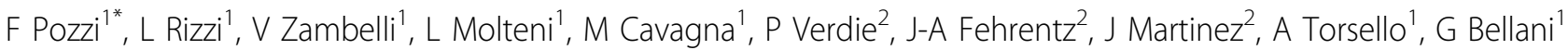 \\ , A Pesenti ${ }^{1}$
}

From ESICM LIVES 2015

Berlin, Germany. 3-7 October 2015

\section{Introduction}

TLQP-21 is a neuropeptide expressed in the brain that is involved in the control of energy homeostasis. In preliminary experiments we have observed that TLQP-21 can modulate macrophage function. In Acute Respiratory Distress Syndrome (ARDS) macrophage seems to play a critical role, contributing to lung remodeling.

\section{Objectives}

To explore the therapeutic role of a short analog of TLQP-21 (JMV5656) in an experimental model of ARDS.

\section{Methods}

C57/BL6 mice received an instillation of $0.1 \mathrm{M} \mathrm{HCl}, 2.5$ $\mathrm{ml} / \mathrm{kg}$ into the right bronchus. They were treated with TLQP-21 $0.6 \mathrm{mg} / \mathrm{kg}$ ip or vehicle control, 2 days before and on the same day of $\mathrm{HCl}$ challenge. Respiratory system compliance, blood gas analysis and differential cell counts in a selective bronchoalveolar lavage (BAL) were determined $24 \mathrm{~h}$ after $\mathrm{HCl}$. In a parallel experiment mice were observed for 14 days to assess epithelial damage and lung fibrosis.
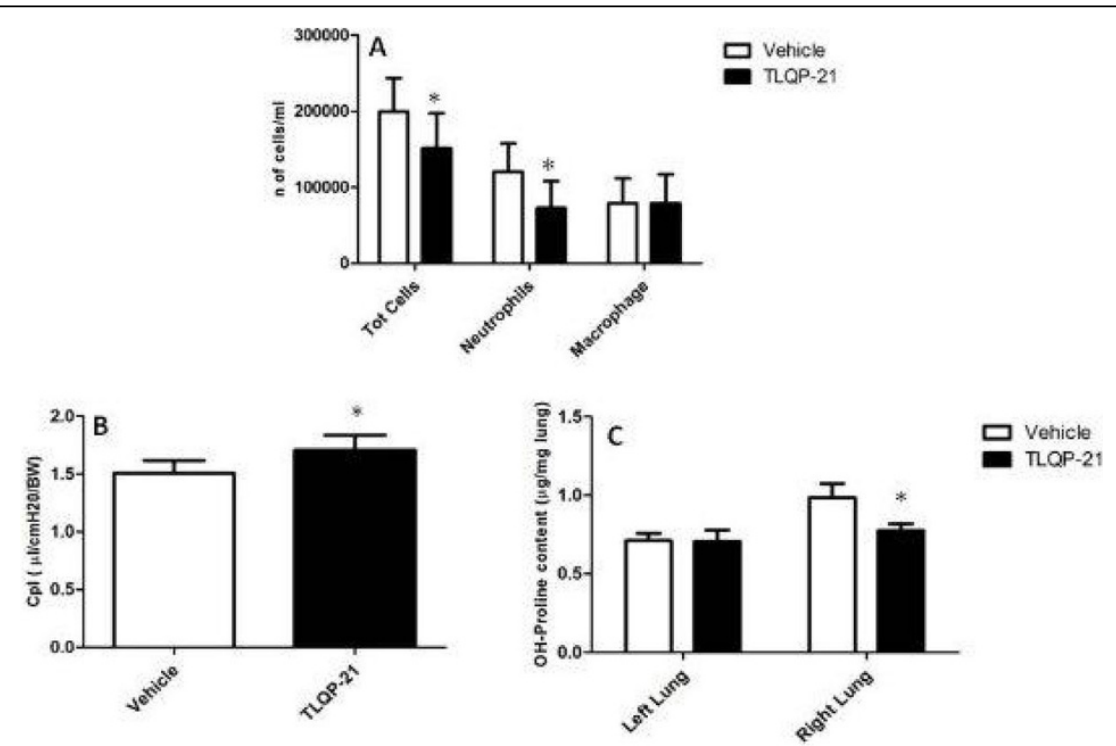

Figure 1 TLQP-21 module lung inflammation and fibrosis. A) Lower neutrophil count in the BALF of the right bronchus at 24 hours after $\mathrm{HCl}$. B) At day 14 lung compliance improved. C) Collagen deposition was lower in the mice treated with TLQP-21. ${ }^{*} \mathrm{p} \leq 0.05$.

\footnotetext{
${ }^{1}$ Università degli Studi di Milano Bicocca, Department of Health Science,
} Monza, Italy

(c) 2015 Pozzi et al.; This is an Open Access article distributed under the terms of the Creative Commons Attribution License (http:// creativecommons.org/licenses/by/4.0), which permits unrestricted use, distribution, and reproduction in any medium, provided the original work is properly cited. 


\section{Results}

The treatment with TLQP-21 showed a significant decrease in the number of total cells in BALF, due to a lower recruitment of neutrophils at 24 hour after challenge with $\mathrm{HCl}$, compared to the vehicle group (Figure 1A), with no differences in macrophage number, even if this did not translate in a functional improvement in lung compliance and oxygenation. At day 14 the TLQP-21 group showed an improvement in lung compliance (Figure 1B) and a decrease collagen deposition in lung tissue (Figure 1C).

\section{Conclusion}

TLQP-21 can decrease inflammatory response at an early phase in a mouse model of $\mathrm{HCl}$-induced ARDS, which may modulate lung remodeling at a late phase, preventing a fibrotic evolution. Given these encouraging but not definitive results we aim to furtherassess the potential therapeutic effect of a higher dose of TLQP-21

\section{Authors' details}

'Università degli Studi di Milano Bicocca, Department of Health Science, Monza, Italy. ${ }^{2}$ Institut des Biomelecules Max Mousseron, Montpellier, France.

Published: 1 October 2015

doi:10.1186/2197-425X-3-S1-A562

Cite this article as: Pozzi et al:: TLQP-21 modulate inflammation and fibrosis in a model of ards. Intensive Care Medicine Experimental 2015 3(Suppl 1):A562.

\section{Submit your manuscript to a SpringerOpen ${ }^{\circ}$ journal and benefit from:}

- Convenient online submission

- Rigorous peer review

- Immediate publication on acceptance

- Open access: articles freely available online

- High visibility within the field

- Retaining the copyright to your article

Submit your next manuscript at $\gg$ springeropen.com 